\title{
Optimalisasi Kualitas Layanan dan Promosi Pada Cafe Herbal J\&J SMK N 1 Purwokerto
}

\author{
Aldila Krisnaresanti ${ }^{1}$ \\ Universitas Jenderal Soedirman Purwokerto, aldila.krisna2104@gmail.com \\ Aldila Dinanti ${ }^{2}$ \\ Universitas Jenderal Soedirman Purwokerto, aldiladinanti88@gmail.com \\ Lina Rifda Naufalin ${ }^{3}$ \\ Universitas Jenderal Soedirman Purwokerto, linarifda@gmail.com
}

\begin{abstract}
Abstrak
Business Centre "KSM" SMK N 1 merupakan tempat praktik siswa SMK Negeri 1 Purwokerto untuk menerapkan ilmunya. Salah satu unit usaha di Business Centre SMK N 1 Purwokerto adalah Café Herbal J\&J. Café Herbal J\&J digunakan sebagai tempat untuk menjual produk yang dihasilkan oleh bidang keahlian farmasi klinis dan komunitas. Selain sebagai tempat penjualan produk, Café Herbal J\&J juga menjadi laboratorium wirausaha siswa bidang keahlian farmasi klinis dan komunitas. Permasalahan di Café Herbal J\&J yang menjadi prioritas untuk diselesaikan dalam program pengabdian ini adalah sebagai berikut: 1) Mitra sudah membuat unit usaha cafe herbal J\&J namun tingkat penjualannya masih rendah; 2) Mitra belum memiliki SOP dalam hal pelayanan kepada pelanggan; 3) Mitra belum memiliki meja bar sehingga masih kurang menarik; 4) Mitra belum memiliki perencanaan pemasaran online atas unit usaha cafe herbal; 5) Mitra belum memiliki perencanaan promosi pada media yang ada; 6) Siswa bidang keahlian farmasi klinis dan komunitas belum memiliki keahlian dalam melayani pembeli; 7) Peralatan dan perlengkapan yang dimiliki mitra untuk menjalankan unit usaha cafe herbal masih terbatas. Kegiatan pengabdian penerapan IPTEKS bertujuan untuk optimalisasi kualitas layanan dan promosi sehingga diharapkan dapat meningkatkan kuantitas penjualan pada Cafe Herbal J\&J. Kegiatan yang dilaksanakan yaitu pembelian meja bar, pelatihan pelayanan prima, dan pelatihan promosi online. Berdasarkan hasil evaluasi yang dilakukan maka dapat diketahui bahwa peserta pelatihan sudah memahami pentingnya perencanaan pelayanan dan promosi, sudah memahami pentingnya pengorganisasian pelayanan dan promosi; dan sudah memahami tentang SOP pelayanan pada pembeli.
\end{abstract}

Kata Kunci : Pelayanan Prima; Digital Marketing; Business Centre

\section{Abstract}

The "KSM" Business Centre of SMK Negeri 1 is a place where students practice to apply their knowledge at SMK Negeri 1 Purwokerto. One of the units of SMK Negeri 1 Business Centre is JEJ Herbal Cafe. JEJ herbal Café is used as a place for selling products manufactured by clinical and community pharmacy courses. Aside from being a place for 


\section{JURNAL ABDIMAS BSI}

Jurnal Pengabdian Kepada Masyarakat

selling products, JEJ Herbal Café also serves as an entrepreneurial laboratory for students in clinical and community pharmacy skill courses. The problems at JEJ Herbal Café which are the priority to be resolved in this service program are as follows: 1) Partners have established a JEJ herbal cafe business unit but the level of sales is still low; 2) Partners do not have SOPs in terms of service to customers; 3) Partners do not yet have a bar so it is still not attractive; 4) Partners do not yet have an online marketing plan for the herbal cafe business unit; 5) Partners do not have promotion plans in the existing media; 6) Students in clinical and community pharmacy expertise do not yet have expertise in serving buyers; 7) Equipment owned by partners to run herbal cafe business units are still limited. Community service implementation of technology, arts, and science (IPTEKS) aims to optimize service quality and promotion in hope to increase sales at JEJ Herbal Café. Activities carried out include purchasing a bar table, providing excellent service training, and online promotion training. Based on the results of the evaluation, it can be considered that training participants have already understood the importance of service and promotion planning, organization, and also standard operational procedures (SOP) of services to buyer.

Keywords: Excellent service; Digital marketing; Business Centre

\section{Pendahuluan}

Business Centre di SMK N 1 Purwokerto mulai dibentuk sejak tahun 2005, dengan unit produksi yang dijalankan pertama adalah Minimarket Pusatrama. Setelah itu diikuti dengan berdirinya unit produksi yang lain diantaranya kantin, fotokopi, diikuti Obelix Multimedia, Aegis Service Komputer, Nusa Kariema, biro teknik, dan air minum SS Water. Business Centre tersebut memiliki nama Business Center "KSM" SMK Negeri 1 Purwokerto. Semua unit usaha dibentuk dengan tujuan memberikan fasilitas laboratorium praktek siswa sesuai dengan jurusannya.

Apabila ditinjau dari aspek pembelajaran, business centre memiliki fungsi sebagai center tempat praktik wirausaha dan wahana menumbuhkan serta mengembangkan jiwa kewirausahaan untuk bekal setelah lulus SMK melalui praktik langsung sesuai dengan kompetensi keahlian masing-masing (learning by doing). Berdasarkan hasil penelitian (Lina Rifda Naufalin, 2017) dijelaskan bahwa business centre memang didirikan sesuai aturan bahwa SMK wajib memiliki business center sebagai tempat praktik siswa.

Business Center "KSM" SMK N 1 telah menjadi laboratorium siswa dalam kegiatan praktik. Minimarket Pusatrama digunakan sebagai tempat praktek siswa jurusan pemasaran. Kantin digunakan sebagai tempat praktek siswa jurusan akuntansi. Fotokopi digunakan sebagai tempat praktik siswa jurusan administrasi perkantoran dan akuntansi. Obelix Multimedia digunakan sebagai tempat praktik jurusan multimedia, Aegis Servis Komputer sebagai tempat praktik siswa jurusan teknik komputer dan jaringan serta rekayasa perangkat lunak. Nusa Kariema sebagai tempat praktik siswa jurusan administrasi perkantoran. Biro teknik dan air minum sebagai tempat praktik semua siswa yang mendapat giliran. Sedangkan laboratorium Bank Syariah Assalam sebagai tempat praktik siswa jurusan perbankan syariah.

Berdasarkan kegiatan yang dijalankan, setiap unit usaha yang ada di business center mampu menghasilkan keuntungan. Keuntungan yang diperoleh bukan tujuan 
utama dari kegiatan business center tetapi keuntungan tersebut dapat membantu kegiatan operasional kegiatan business center antara lain untuk operasional kegiatan business center, manajemen, peningkatan mutu, seragam guru, dan pelaksanaan kegiatan sekolah, seperti pemberian bea siswa ke murid, menjadi sponsor dalam acara yang diadakan siswa dan membayar petugas business center yang di ambil dari luar sekolah.

Pada tahun 2018, Business Centre SMK N 1 Purwokerto menambah unit usaha baru bernama Café Herbal J\&J. Café Herbal J\&J merupakan unit usaha yang digunakan untuk praktik bidang keahlian farmasi klinis dan komunitas. Minuman yang disajikan berasal dari bahan-bahan alami, antara lain wedhang jahe, wedhang uwuh, bubuk jamu harbal, jus kombinasi untuk mengobati penyakit khusus, makanan herbal, dan sebagainya.

Berdasarkan hasil wawancara dengan pengelola Café Herbal J\&J, penyelenggaraan Café Herbal J\&J masih menemui beberapa permasalahan terutama dalam hal pelayanan dan promosi. Hasil penjualan di cafe herbal J\&J belum maksimal karena belum memaksimalkan media promosi yang ada. Banyaknya siswa SMK Negeri 1 Purwokerto merupakan suatu peluang besar bagi Cafe herbal untuk terus berusaha meningkatkan kualitas layanan dan promosinya sehingga diharapkan penjualannya dapat meningkat pula.

Berdasarkan uraian di atas, maka permasalahan mitra yang menjadi prioritas untuk diselesaikan dalam program pengabdian ini adalah sebagai berikut:

1. Mitra sudah membuat unit usaha cafe herbal J\&J namun tingkat penjualannya masih rendah.

2. Mitra belum memiliki SOP dalam hal pelayanan kepada pelanggan

3. Mitra belum memiliki meja bar sehingga masih kurang menarik

4. Mitra belum memiliki perencanaan pemasaran online atas unit usaha cafe herbal

5. Mitra belum memiliki perencanaan promosi pada media yang ada

6. Siswa bidang keahlian farmasi klinis dan komunitas belum memiliki keahlian dalam melayani pembeli.

7. Peralatan dan perlengkapan yang dimiliki mitra untuk menjalankan unit usaha cafe herbal masih terbatas.

Pada kegiatan pengabdian penerapan IPTEKS ini dikhususkan pada optimalisasi kualitas layanan dan promosi sehingga diharapkan dapat meningkatkan kuantitas penjualan pada Cafe Herbal J\&J. Kegiatan yang dilakukan mencakup perencanaan pelayanan dan promosi, pengorganisasian pelayanan dan promosi, pelaksanaan pelayanan dan promosi, pengawasan pelayanan dan promosi, serta evaluasi pelayanan dan promosi. Adapun tujuan umum kegiatan pengabdian ini adalah sebagai berikut:

1. Meningkatkan pengetahuan pengurus cafe dan siswa dalam mengelola cafe sesuai dengan fungsi-fungsi manajemen khususnya pada aspek pelayanan dan promosi.

2. Menghasilkan tampilan cafe yang lebih menarik perhatian pengunjung

3. Meningkatkan jiwa kewirausahaan siswa SMK N 1 Purwokerto khususnya bidang keahlian Farmasi Klinis dan Komunitas. 
Dengan adanya peningkatan kemampuan pengurus dalam manajemen organisasi khususnya pada aspek pelayanan dan promosi serta peningkatan tampilan cafe menjadi lebih menarik maka dapat memberikan manfaat bagi seluruh pihak khususnya bagi Café Herbal J\&J. Cafe herbal J\&J dapat menjadi tempat untuk meningkatkan jiwa kewirausahaan siswa sekaligus dapat membekali siswa ketika akan menjadi wirausahawan kelak. Kegiatan pengabdian ini juga sebagai bentuk sumbangsih Universitas Jenderal Soedirman (UNSOED) di masyarakat yaitu sebagai Universitas yang aktif memasok teknologi dan pengetahuan tepat guna untuk kawasan pedesaan sehingga dapat membantu mewujudkan Desa Mandiri Sejahtera.

Henry Fayol ( (Safroni, 2012)) menyebutkan fungsi-fungsi manajemen meliputi perencanaan (planning), pengorganisasian (organizing), pengarahan (commanding), pengkoordinasian (coordinating), pengendalian (controlling). Manajemen organisasi dalam hal ini business center merupakan proses lanjutan setelah proses penentuan strategi untuk mencapai visi dan misi organisasi. Manajemen organisasi meliputi kegiatan-kegiatan yang menyangkut keberhasilan pengelolaan organisasi, diantaranya adalah manajemen kelompok, manajemen keuangan, dan pengelolaan administrasi.

Pada kegiatan pengabdian penerapan IPTEKS ini dikhususkan pada optimalisasi kualitas layanan dan promosi sehingga diharapkan dapat meningkatkan kuantitas penjualan pada Cafe Herbal J\&J. Kegiatan yang dilakukan mencakup perencanaan pelayanan dan promosi, pengorganisasian pelayanan dan promosi, pelaksanaan pelayanan dan promosi, pengawasan pelayanan dan promosi, serta evaluasi pelayanan dan promosi.

\section{Metode}

Kegiatan pengabdian dilaksanakan di Café Herbal J\&J yang artinya Café j\&J berlaku sebagai mitra kegiatan pengabdian. Kegiatan ini melibatkan pengelola business centre, pengelola Café Herbal Herbal J\&J, perwakilan pengelola kantin siswa, dan siswa bidang keahlian farmasi klinis dan komunitas. Metode yang ditawarkan mengatasi permasalahan yang dihadapi mitra adalah dengan melaksanakan kegiatan penyuluhan, pelatihan dan pendampingan tentang manajemen organisasi. Adapun kegiatan yang dilakukan pada kegiatan pengabdian dapat dilihat pada Tabel 1 berikut ini:

Tabel. 1 Metode pelaksanaan kegiatan dan partisipasi mitra.

\begin{tabular}{|l|l|l|l|}
\hline No. & Solusi yang ditawarkan & \multicolumn{1}{|c|}{ Kegiatan } & \multicolumn{1}{c|}{ Partisipasi Mitra } \\
\hline 1. & $\begin{array}{l}\text { Pemberian bantuan } \\
\text { perlengkapan cafe dan } \\
\text { meja bar yang menarik } \\
\text { dan kekinian sehingga } \\
\text { tampilan cafe lebih fresh } \\
\text { dan menarik siswa } \\
\text { untuk membeli di cafe }\end{array}$ & $\begin{array}{l}\text { Tim Pengabdi dan mitra } \\
\text { bersama-sama membeli } \\
\text { perlengkapan cafe dan meja } \\
\text { bar dibutuhkan untuk cafe } \\
\text { herbal. }\end{array}$ & Penerima bantuan alat \\
\hline 2. & $\begin{array}{l}\text { Penyuluhan mengenai } \\
\text { pentingnya } \\
\text { perencanaan pelayanan } \\
\text { dan promosi }\end{array}$ & $\begin{array}{l}\text { FGD tentang perencanaan } \\
\text { pelayanan dan promosi cafe } \\
\text { herbal }\end{array}$ & $\begin{array}{l}\text { Mendengarkan, mencatat, } \\
\text { mendiskusikan, dan membuat } \\
\text { perencanaan pelayanan dan promosi } \\
\text { cafe herbal }\end{array}$ \\
\hline
\end{tabular}


Jurnal Pengabdian Kepada Masyarakat

\begin{tabular}{|l|l|l|l|}
\hline 3. & $\begin{array}{l}\text { Penyuluhan mengenai } \\
\text { pentingnya } \\
\text { pengorganisasian } \\
\text { pelayanan dan promosi }\end{array}$ & $\begin{array}{l}\text { Pembentukan struktur } \\
\text { organisasi pelayanan dan } \\
\text { promosi usaha cafe herbal, } \\
\text { membuat rincian tugas dan } \\
\text { wewenang bagian pelayanan } \\
\text { dan promosi }\end{array}$ & $\begin{array}{l}\text { Mendengarkan, mencatat, membuat } \\
\text { struktur organisasi pelayanan dan } \\
\text { promosi usaha cafe herbal, membuat } \\
\text { rincian tugas dan wewenang bagian } \\
\text { pelayanan dan promosi }\end{array}$ \\
\hline 4. & $\begin{array}{l}\text { Penyuluhan tentang } \\
\text { SOP pelayanan pada } \\
\text { pembeli }\end{array}$ & $\begin{array}{l}\text { Penyuluhan tentang } \\
\text { pelayanan pada pembeli }\end{array}$ & $\begin{array}{l}\text { Mendengarkan, mencatat, } \\
\text { mempraktikkan melayani pembeli }\end{array}$ \\
\hline 5. & $\begin{array}{l}\text { Praktek kegiatan } \\
\text { pemasaran on-line dan } \\
\text { promosi produk }\end{array}$ & $\begin{array}{l}\text { Praktek kegiatan pemasaran } \\
\text { on-line dan promosi produk }\end{array}$ & $\begin{array}{l}\text { Mendengarkan, mencatat, } \\
\text { mempraktikkan promosi produk } \\
\text { secara online }\end{array}$ \\
\hline
\end{tabular}

Tim pengabdian melakukan evaluasi pelaksanaan kegiatan pengabdian dengan mengacu pada target luaran atau tolok ukur keberhasilan kegiatan yang telah ditetapkan pada setiap kegiatan. Kegiatan pelatihan dievaluasi dengan melakukan pre test dan posttest untuk mengetahui tingkat pemahaman peserta pelatihan. Adapun kegiatan dan target luarannya adalah sebagai berikut :

Tabel 2. Kegiatan dan target luaran

\begin{tabular}{|c|l|l|}
\hline No & Kegiatan & Tolok ukur keberhasilan \\
\hline 1 & $\begin{array}{l}\text { Pemberian bantuan perlengkapan cafe dan } \\
\text { meja bar yang menarik dan kekinian } \\
\text { sehingga tampilan cafe lebih fresh dan } \\
\text { menarik siswa untuk membeli di cafe }\end{array}$ & $\begin{array}{l}\text { Kelompok memiliki perlengkapan cafe dan } \\
\text { meja bar. }\end{array}$ \\
\hline 2 & $\begin{array}{l}\text { Penyuluhan mengenai pentingnya } \\
\text { perencanaan pelayanan dan promosi }\end{array}$ & $\begin{array}{l}\text { Peserta memahami pentingnya perencanaan } \\
\text { pelayanan dan promosi }\end{array}$ \\
\hline 3 & $\begin{array}{l}\text { Penyuluhan mengenai pentingnya } \\
\text { pengorganisasian pelayanan dan promosi }\end{array}$ & $\begin{array}{l}\text { Peserta memahami pentingnya } \\
\text { pengorganisasian pelayanan dan promosi }\end{array}$ \\
\hline 4 & $\begin{array}{l}\text { Penyuluhan tentang SOP pelayanan pada } \\
\text { pembeli }\end{array}$ & $\begin{array}{l}\text { Peserta memahami tentang SOP pelayanan } \\
\text { pada pembeli }\end{array}$ \\
\hline 5 & $\begin{array}{l}\text { Praktik kegiatan pemasaran on-line dan } \\
\text { promosi produk }\end{array}$ & $\begin{array}{l}\text { Peserta mempraktikkan digital marketing } \\
\text { bagi produk café herbal J\&J }\end{array}$ \\
\hline
\end{tabular}

\section{Hasil dan Pembahasan}

1. Koordinasi dengan pengelola Business Centre "KSM" SMK N 1 Purwokerto dan pengelola Café Herbal J\&J

Koordinasi antara tim pengabdian penerapan IPTEKS dengan pengelola business centre dan pengelola Café Herbal J\&J dilakukan pada tanggal 21 Juni 2019. Koordinasi dilakukan untuk membahas waktu pelaksanaan penyuluhan dan praktik digital marketing serta peserta yang mengikuti penyuluhan. Selain itu juga membahas mengenai meja bar yang akan diberikan oleh tim pengabdian untuk café herbal J\&J

\section{Pembelian meja bar untuk Café Herbal J\&J}


Jurnal Pengabdian Kepada Masyarakat

Pembelian meja bar dilakukan untuk memaksimalkan pelayanan pada Café Herbal J\&J. Meja bar didesain secara minimalis menyesuaikan luas café.

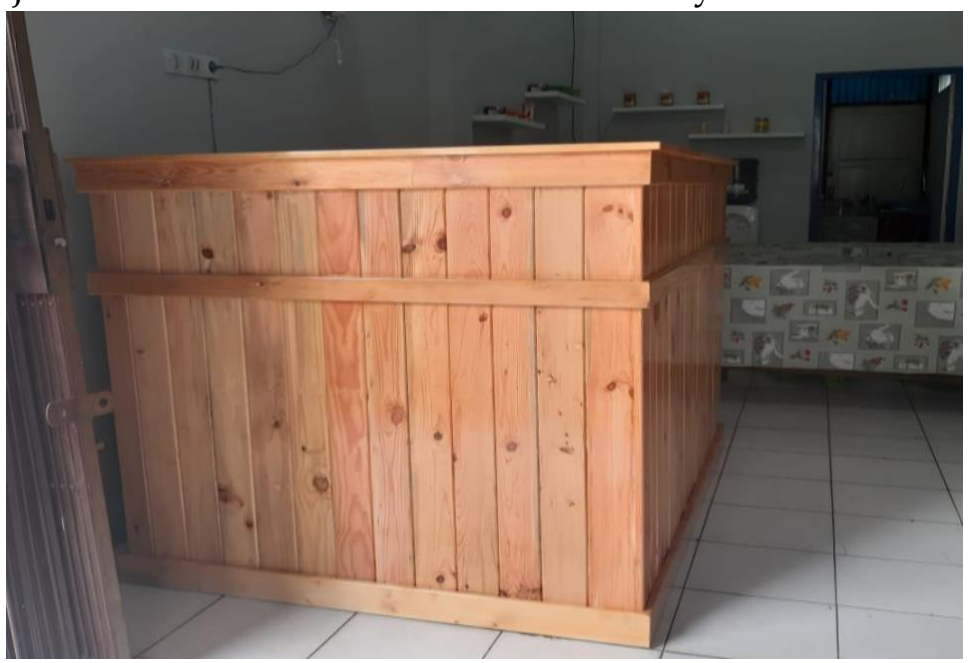

Gambar 1. Meja Bar

\section{Pelatihan tentang pelayanan prima}

Pelayanan prima kepada pelanggan merupakan salah satu aspek yang sangat penting diperhatikan dalam merebut simpati konsumen sehingga konsumen memilih produk yang ditawarkan. Seiring perkembangan teknologi, pelayanan prima dilakukan tidak hanya secara tatap muka, tetapi secara online juga dibutuhkan dalam menarik perhatian konsumen. Cafe herbal J\&J yang baru memulai bersaing dalam dunia kuliner juga tidak terlepas dari persaingan usaha yang sejenis. Melalui pelatihan pelayanan prima kepada pelanggan ini, diharapkan cafe J \& J mampu meningkatkan penjualan dan lebih dikenal masyarakat. Pelatihan pelayanan prima dilaksanakan pada tanggal 21 Juli 2019 dengan diikuti oleh guru bidang keahlian Farmasi Klinis dan Komunitas, perwakilan siswa bidang keahlian farmasi klinis dan komunitas, pengurus business centre, dan perwakilan petugas kantin di SMK Negeri 1 Purwokerto.

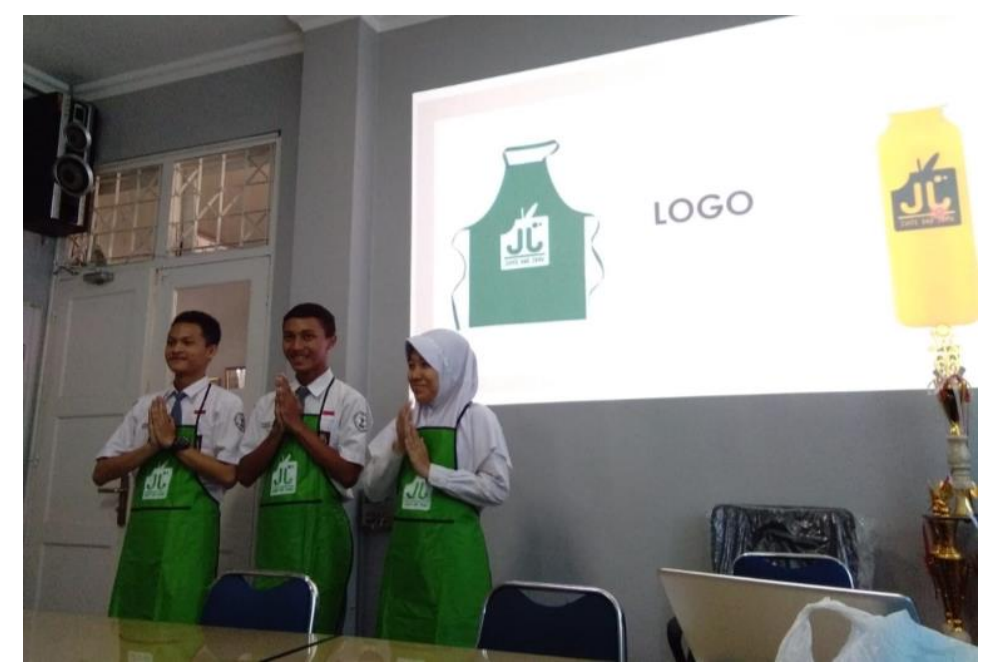

Gambar 2. Praktik melayani konsumen 
Manfaat dari pelayanan prima salah satunya untuk upaya meningkatkan kualitas pelayanan kepada para pelanggan serta dapat menjadi acuan untuk pengembangan penyusunan standar pelayanan. Standar pelayanan merupakan tolak ukur untuk melakukan pelayanan dan juga sebagai acuan untuk menilai kualitas suatu pelayanan. Pelayanan disebut prima jika pelanggan sudah merasa puas dan sesuai dengan harapan pelanggan.

Penyuluhan dan pelatihan mengenai pelayanan prima dilakukan dengan metode praktik langsung. Peserta diberikan penjelasan mengenai definisi pelayanan prima, tujuan pelayanan prima, dan contoh-contoh pelayanan prima yang sudah dilakukan oleh perusahaan-perusahaan. Salah satu yang dijadikan contoh adalah pelayanan di Alfamart. Alfamart sudah memiliki Standart Operational Procedure (SOP) mengenai bagaimana menyapa konsumen yang baru datang ke alfamart, bagaimana pelayanan konsumen ketika ada di kasir, dan bagaimana memberikan kesan dan pesan bagi konsumen untuk datang kembali ke Alfamart.

Pelatihan mengenai pelayanan prima difokuskan pada tiga konsep utama, yaitu konsep sikap (attitude), konsep perhatian (attention), dan konsep tindakan (action).

1. Konsep Sikap / Attitude

Sikap yang harus dimiliki untuk mencapai pelayanan prima diantaranya sikap yang ramah, penuh perhatian, dan memiliki rasa bangga terhadap perusahaan. Peserta pelatihan langsung praktik cara menyapa pelanggan dengan sapaan khas Café Herbal J\&J.

2. Konsep Perhatian / Attention

Bentuk perhatian yang dapat diberikan kepada konsumen yaitu dengan bertanya apa saja yang diinginkan konsumen. Penjual harus memberikan pelayanan dengan ramah, cepat dan tepat dalam menempatkan kepentingan konsumen.

3. Konsep tindakan / Action

Dalam konsep tindakan, misalnya seorang pegawai pada bagian pelayanan harus selalu memperhatikan dan mencermati apa yang menjadi keinginan konsumen. Beberapa bentuk pelayanan pada konsep tindakan yaitu dengan mencatat pesanan konsumen, mengecek kembali yang di pesan konsumen, menyelesaikan transaksi pesanan pelanggan, dan mengucapkan terimakasih kepada konsumen setelah pelayanan selesai.

Pada saat pelatihan, peserta pelatihan diberikan kesempatan untuk menciptakan sapaan bagi konsumen Café Herbal J\&J sekaligus mempraktikannya. Selain itu, peserta pelatihan juga langsung menggunakan celemek seperti saat melayani konsumen di café herbal. Tentunya kegiatan ini bertujuan untuk membekali peserta pelatihan agar semakin handal dalam melayani pelanggan.

\section{Pelatihan tentang digital marketing}

Digital Marketing merupakan istilah umum untuk kegiatan pemasaran produk atau jasa yang ditargetkan, terukur, dan interaktif produk atau dengan 
menggunakan teknologi digital untuk mencapai dan memberikan suatu arah perubahan bagi pelanggan dan mempertahankan mereka (Saveria, 2016). Digital marketing juga dapat didefinisikan sebagai kegiatan marketing termasuk branding yang menggunakan berbagai media berbasis web (Wardhana, 2015). Branding sendiri merupakan suatu kegiatan untuk membangun brand. Brand atau merek adalah nama, tanda, istilah, simbol, desain, kata atau kombinasi dari halhal tersebut yang ditujukan untuk mengidentifikasi serta membedakan antara produk dan jasa yang satu dengan yang lainnya.

Salah satu kegiatan pengabdian di Café Herbal J\&J adalah dengan branding. Café herbal belum memiliki logo brand yang dapat disertakan pada kemasan produknya. Branding logo café herbal J\&J didesain dengan mengangkat tema segar dan berkaitan dengan jus dan jamu sebagai produk utama café herbal. Adapun logo yang berhasil didesain dapat dilihat pada gambar 3 .

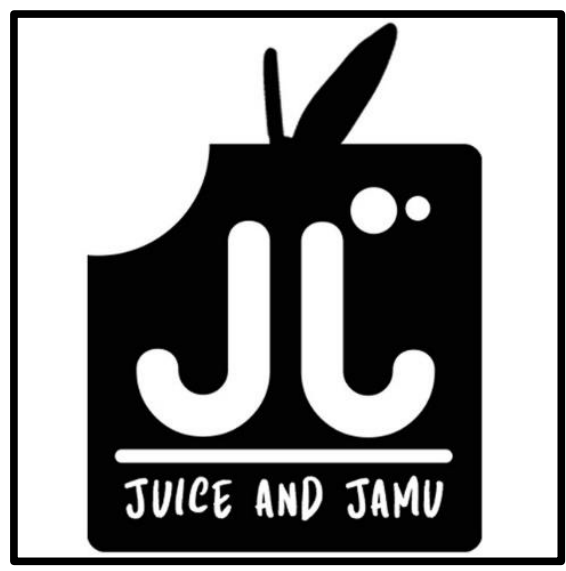

Gambar 3. Logo Café Herbal J\&J

\section{Keberhasilan Kegiatan}

Keberhasilan kegiatan dapat dilihat dari tolok ukur keberhasilan kegiatan. Evaluasi dilakukan melalui pretest dan posttest. Adapun capaian yang berhasil diperoleh selama kegiatan pengabdian di Café Herbal J\&J tampak pada Tabel 3 berikut ini:

Tabel 3. Capaian kegiatan pengabdian di Café Herbal J\&J

\begin{tabular}{|c|l|l|}
\hline No & Kegiatan & \multicolumn{1}{|c|}{ Bukti } \\
\hline 1 & $\begin{array}{l}\text { Pemberian bantuan perlengkapan cafe dan } \\
\text { meja bar yang menarik dan kekinian } \\
\text { sehingga tampilan cafe lebih fresh dan } \\
\text { menarik siswa untuk membeli di cafe }\end{array}$ & $\begin{array}{l}\text { Café Herbal J\&J sudah memiliki } \\
\text { perlengkapan cafe dan meja bar. }\end{array}$ \\
\hline 2 & $\begin{array}{l}\text { Penyuluhan mengenai pentingnya } \\
\text { perencanaan pelayanan dan promosi }\end{array}$ & $\begin{array}{l}\text { Peserta pelatihan sudah memahami } \\
\text { pentingnya perencanaan pelayanan dan } \\
\text { promosi }\end{array}$ \\
\hline
\end{tabular}


Jurnal Pengabdian Kepada Masyarakat

\begin{tabular}{|c|l|l|}
\hline 3 & $\begin{array}{l}\text { Penyuluhan mengenai pentingnya } \\
\text { pengorganisasian pelayanan dan promosi }\end{array}$ & $\begin{array}{l}\text { Peserta pelatihan sudah memahami } \\
\text { pentingnya pengorganisasian pelayanan } \\
\text { dan promosi }\end{array}$ \\
\hline 4 & $\begin{array}{l}\text { Penyuluhan tentang SOP pelayanan pada } \\
\text { pembeli }\end{array}$ & $\begin{array}{l}\text { Peserta pelatihan sudah memahami } \\
\text { tentang SOP pelayanan pada pembeli }\end{array}$ \\
\hline 5 & $\begin{array}{l}\text { Praktik kegiatan pemasaran on-line dan } \\
\text { promosi produk }\end{array}$ & $\begin{array}{l}\text { Peserta pelatihan sudah mampu } \\
\text { mempraktikkan digital marketing bagi } \\
\text { produk café herbal J\&J }\end{array}$ \\
\hline
\end{tabular}

\section{Simpulan dan Rekomendasi}

Kegiatan pengabdian dilakukan di Café Herbal J\&J SMK Negeri 1 Purwokerto. Kegiatan yang dilaksanakan antara lain pembelian perlengkapan café dan meja bar, pelatihan pelayanan prima, dan pelatihan digital marketing. Kegiatan pelatihan pelayanan prima dan promosi mencakup pentingnya perencanaan pelayanan dan promosi sehingga peserta pelatihan mampu memahami tentang pentingnya pelayanan dan promosi melalui media digital.

Rekomendasi yang dapat diberikan yaitu sebaiknya pengurus Café Herbal J\&J membentuk suatu tim yang terdiri dari siswa-siswi bidang keahlian farmasi klinis dan komunitas. Tim tersebut diberikan edukasi dan tanggung jawab terkait dengan pengelolaan media pemasaran digital café herbal J\&J.

\section{Acknowledgements}

Ucapan terimakasih penulis ucapkan kepada Lembaga Penelitian dan Pengabdian Masyarakat (LPPM) Universitas Jenderal Soedirman (UNSOED) Purwokerto yang telah membiayai kegiatan pengabdian kepada masyarakat ini melalui skim program penerapan IPTEKS Pendanaan Tahun 2019.

\section{Daftar Pustaka}

Lina Rifda Naufalin, A. D. (2017). Analysis of Business Center Implementation in Banyumas Regency. Dinamika Pendidikan, 76-85.

Safroni, L. (2012). Manajemen dan Reformasi Pelayanan Publik: dalam Konteks Birokrasi Indonesia. Malang: Aditya Media Publishing.

Saveria, R. A. (2016). Analisis Digital Marketing Dalam Strategi Integrated Marketing Communication Kampanye Politik (Studi Kasus Komunitas Teman Ahok) Makalah NonSeminar. Jakarta: Universitas Indonesia.

Wardhana, A. (2015). Strategi Digital Marketing dan Implikasinya pada Keunggulan Bersaing UKM di Indonesia . Prosiding Seminar Nasional ISBN : 978-602-17225-4-1 Forum Keuangan dan Bisnis IV (hal. 327-337). Bandung : UPI Bandung. 